Office of Planning and Managment

\title{
OAK RIDGE NATIONAL LABORATORY CORE COMPETENCIES
}

\author{
J. B. Roberto \\ T. D. Anderson \\ B. A. Berven \\ S. G. Hildebrand \\ F. C. Hartman \\ R. B. Honea \\ J. E. Jones Jr. \\ R. M. Moon, Jr. \\ M. J. Saltmarsh \\ R. B. Shelton \\ R. C. Ward
}

Date Published-December 1994

Prepared by the OAK RIDGE NATIONAL LABORATORY

Oak Ridge, Tennessee 37831-6285

managed by

MARTIN MARIETTA ENERGY SYSTEMS, INC.

for the

U.S. DEPARTMENT OF ENERGY

under contract DE-AC05-84OR21400

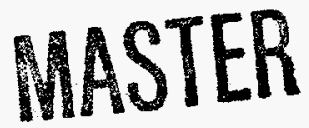




\section{DISCLAIMER}

This report was prepared as an account of work sponsored by an agency of the United States Government. Neither the United States Government nor any agency thereof, nor any of their employees, make any warranty, express or implied, or assumes any legal liability or responsibility for the accuracy, completeness, or usefulness of any information, apparatus, product, or process disclosed, or represents that its use would not infringe privately owned rights. Reference herein to any specific commercial product, process, or service by trade name, trademark, manufacturer, or otherwise does not necessarily constitute or imply its endorsement, recommendation, or favoring by the United States Government or any agency thereof. The views and opinions of authors expressed herein do not necessarily state or reflect those of the United States Government or any agency thereof. 


\title{
DISCLAIMER
}

\author{
Portions of this document may be illegible \\ in electronic image products. Images are \\ produced from the best available original \\ document.
}




\section{ORNL Core Competencies}

\section{Contents}

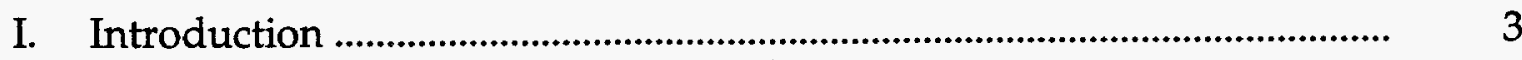

- ORNL Core Competency Matrix ................................................................ 5

II. Core Competency Descriptions

- Energy Production and End-Use Technologies ....................................... 9

- Biological and Environmental Sciences and Technologies .................... 13

- Advanced Materials Synthesis, Processing, and Characterization ..... 19

- Neutron-Based Science and Technology .................................................. 23

III. Emerging Core Competencies

- Oak Ridge Manufacturing Technologies ..................................................... 29

- Computational Science and Advanced Computing ............................... 35

IV. Institutional Competencies

- Development and Operation of National Research Facilities .............. 41

- R\&D Integration and Partnerships ............................................................. 45

- Technology Transfer ........................................................................................ 47

- Science Education ....................................................................................... 49

\section{Appendices}

A. Competency Funding by ORNL Program.............................................. 53

B. Competency Funding by ORNL Division/Office ................................... 55

C. Program Funding by ORNL Division/Office .......................................... 57 
I. INTRODUCTION 
This page intentionally left blank. 
A core competency is a distinguishing integration of capabilities which enables an organization to deliver mission results. ${ }^{*}$ Core competencies represent the collective learning of an organization and provide the capacity to perform present and future missions. Core competencies are distinguishing characteristics which offer comparative advantage and are difficult to reproduce. They exhibit customer focus, mission relevance, and vertical integration from research through applications. They are demonstrable by metrics such as level of investment, uniqueness of facilities and expertise, and national impact.

The Oak Ridge National Laboratory (ORNL) has identified four core competencies which satisfy the above criteria. Each core competency represents an annual investment of at least $\$ 100 \mathrm{M}$ and is characterized by an integration of Laboratory technical foundations in physical, chemical, and materials sciences; biological, environmental, and social sciences; engineering sciences; and computational sciences and informatics. The ability to integrate broad technical foundations to develop and sustain core competencies in support of national R\&D goals is a distinguishing strength of the national laboratories. The ORNL core competencies are:

- Energy Production and End-Use Technologies

- Biological and Environmental Sciences and Technology

- Advanced Materials Synthesis, Processing, and Characterization

- Neutron-Based Science and Technology

The ORNL core competencies and technical foundations are shown in a matrix format in Table 1. This representation shows the level of annual investment in each core competency distributed among the four technical foundations. The total level of effort is somewhat larger than the ORNL budget because of overlap among some of the core competencies. This overlap provides synergy and additional leverage in many mission areas.

The following pages include a description of the distinguishing characteristics of each ORNL core competency, including the integrated capabilities which comprise them. In addition, written material is provided for two emerging competencies: Manufacturing Technologies and Computational Science and Advanced Computing. Distinguishing institutional competencies in the Development and Operation of National Research Facilities, R\&D Integration and Partnerships, Technology Transfer, and Science Education are also described. These institutional competencies cross-cut the core competencies and technical foundations and are important characteristics of the Laboratory as a whole. Finally, financial data for the ORNL core competencies are summarized in the appendices.

*Report of the Missions of the Laboratories Priority Team (February 1994). 
This report was prepared by a committee of division and program leaders representing the broad spectrum of R\&D activities at ORNL. An initial list of 10 candidate core competencies developed by the ORNL Strategic Planning Committee served as a starting point. Profiles were prepared for each candidate core competency focusing on distinguishing characteristics, integration of basic research and applications, mission relevance, customer focus, uniqueness of facilities and expertise, level of effort, and performance metrics. This information was presented to the ORNL Executive Committee which approved further consolidation of the list. The consolidation combined related competencies, eliminated competencies which were derivatives of others, and restricted the final list to R\&D areas representing investments of more than $\$ 100$ million annually. The concept of emerging core competencies and institutional competencies was developed at this time to describe important new directions and special institutional capabilities of the Laboratory. This report documents ORNL's core competencies, emerging core competencies, and institutional competencies. 
Table 1. ORNL Core Competency Matrix*

\begin{tabular}{|c|c|c|c|c|c|}
\hline \multirow{2}{*}{$\begin{array}{c}\text { Core } \\
\text { Competencies }\end{array}$} & $\begin{array}{c}\text { Physical, Chemical, } \\
\text { and Materials } \\
\text { Sciences }\end{array}$ & $\begin{array}{c}\text { TECHNICAL FOUNDATIONS } \\
\text { Enviological, } \\
\text { Soclal Sclences }\end{array}$ & $\begin{array}{c}\text { Engineering } \\
\text { Sciences }\end{array}$ & $\begin{array}{c}\text { Computational } \\
\text { Sclences and } \\
\text { Informatics }\end{array}$ & \multirow{2}{*}{ TOTAL } \\
\hline $\begin{array}{c}\text { Energy Production and } \\
\text { End-Use Technologies }\end{array}$ & 104 & 12 & 44 & 9 & 169 \\
\hline $\begin{array}{c}\text { Biological and } \\
\text { Environmental } \\
\text { Sciences and } \\
\text { Technology }\end{array}$ & 23 & 88 & 37 & 12 & 160 \\
\hline $\begin{array}{c}\text { Advanced Materials } \\
\text { Synthesis, } \\
\text { Characterization, and } \\
\text { Processing }\end{array}$ & 95 & 1 & 36 & 6 & 137 \\
\hline $\begin{array}{c}\text { Neutron-Based } \\
\text { Science and } \\
\text { Technology }\end{array}$ & 63 & 48 & 6 & 118 \\
\hline
\end{tabular}

"FY 1993 operating expenditures to nearest \$1M. 
This page intentionally left blank. 
II. CORE COMPETENCY DESCRIPTIONS

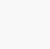

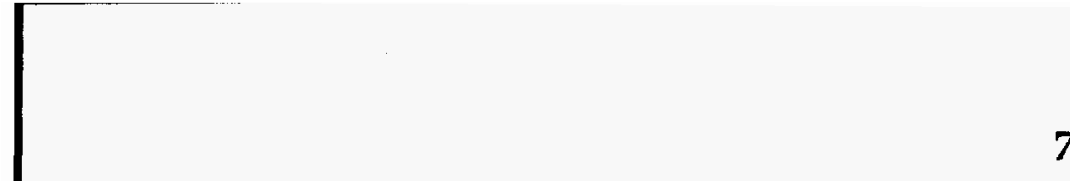

,


This page intentionally left blank. 


\section{ENERGY PRODUCTION AND END-USE TECHNOLOGIES}

\section{Description}

ORNL is one of the world's premier centers for research and development (R\&D) on energy technologies. ORNL's energy R\&D budget is approximately $\$ 170 \mathrm{M}$ per year and involves all aspects of ORNL's scientific and technical activities. The Laboratory's energy program encompasses both production and end-use energy technologies and includes distinguishing capabilities in energy efficiency and renewable energy, fission and fusion reactor technologies, power conversion cycles, refrigeration systems and heat pumps, building envelopes, biomass production and conversion systems, transportation systems, energy storage, internal combustion engines, fossil power systems, and geothermal systems. The program also includes access to unique facilities for energy-related research, development, and testing including the High Flux Isotope Reactor, High Temperature Materials Laboratory, and Buildings Technology Center. The technology work is underpinned by fundamental investigations in the basic energy sciences.

\section{Integrated Capabilities}

The work on energy technologies requires the integration of a large number of scientific and technical skills, including the following core capabilities:

- Heat Transfer and Fluid Flow

- Biomass Energy and Bioprocessing

- Building Systems and Technologies

- Transportation Technologies, Modeling, and Data Systems

- Electric Power Systems

- Thermodynamic Cycles

- Advanced Structural Design and Life Assessment

- Instrumentation, Controls, Remote Sensing, and Advanced Diagnostics

- Fuels and Combustion Technologies

- Advanced Nuclear Reactors: Fuels, Neutronic Analyses, Safety

- Conception, Development, Design, and Fabrication of Advanced Energy Systems and Prototype Machines

- Radiation Effects on Materials

- Superconducting Materials and Technologies

- Plasma Technologies

- Energy Analyses: Economics, Externalities, Technology, Safety

- Design of Advanced Alloys and Composites

- Thermodynamics of High-Temperature Aqueous Systems 


\section{Mission Support}

This core competency supports DOE missions in energy efficiency and renewable energy, fission and fusion energy, fossil energy, and technology transfer. Additional support is provided for DOE defense and environmental management programs. The core competency also provides support for other sponsors including the Nuclear Regulatory Commission, Department of Transportation, Department of Defense, and Environmental Protection Agency.

\section{Examples}

The work on energy R\&D is strongly oriented toward moving technologies from the laboratory to the commercial sector. As a consequence, almost every energy technology program has significant industry involvement. The industry interactions take several forms including Cooperative Research and Development Agreements (CRADAs) and R\&D subcontracts with industry. Examples of energy technology development are as follows:

- Energy Production. Research on the production and conversion of energy includes fission, fusion, biomass, and fossil technologies.

- Fission reactor R\&D emphasizes nuclear safety work for the Nuclear Regulatory Commission and the development of advanced gas-cooled reactors. ORNL's advanced reactor work, which emphasizes fuels, has involved cooperation with Gas Cooled Reactor Associates, an industry consortium. Other examples include pressure vessel failure analysis, advanced reactor concepts, and policy analysis of life extension of nuclear power plants.

- Fusion energy R\&D at the Laboratory is a major component of DOE's Magnetic Fusion Program and involves extensive collaborations both nationally (with numerous universities, industries, and national laboratories) and internationally (with ten countries). The ORNL fusion work includes the integration of physics and technology for plasma-edge physics, particle control, plasma fueling, and If heating; the development of reactor structural materials, ceramics, and first-wall materials; and the development of advanced fusion reactor concepts including the International Thermonuclear Experimental Reactor.

- Biomass energy R\&D at ORNL includes both energy crops and the conversion of biomass to end-use fuels. ORNL is the technical manager for the national program on energy crop development. The Laboratory also does advanced research on the biochemical conversion of biomass and wastes to ethanol and other chemicals. 
- Fossil energy work at ORNL includes materials research; coal combustion; bioprocessing; and environmental, safety, and health (ES\&H) analyses and assessments. The largest activity is materials research, which includes composites, ceramics, and advanced alloys for fossil energy applications. Specific examples include iron aluminides for high-temperature sulfur environments and ceramic membranes for gas separations.

- End-Use Technologies. ORNL works with industry on a wide range of end-use technology $R \& D$ programs sponsored by the DOE Assistant Secretary for Energy Efficiency and Renewable Energy. End-use sectors include buildings, industry, transportation, and utilities.

- Buildings R\&D includes thermal envelope systems and materials and building equipment. An important component of the buildings program is the Buildings Technology Center, a user facility available to industry for testing various elements of buildings and equipment. Contributions include advanced air conditioning and refrigeration systems (absorption heat pumps, chlorofluorocarbon substitution) and testing of insulation and roof systems.

- Industrial energy conservation R\&D includes advanced materials for heat exchangers and other industrial applications, advanced bioprocessing concepts, industrial gas turbines, alternative feedstocks for the chemical and refining industries, and pollution prevention technologies.

- Transportation R\&D involves a broad spectrum of activities, including transportation materials, propulsion technologies, alternative fuels, transportation data, traffic and logistics modeling, and policy analysis. The transportation materials work includes reliable ceramics for use in advanced heat engines, lightweight structural materials, and tribology. The High Temperature Materials Laboratory, one of ORNL's user facilities, houses several dedicated laboratories to support DOE's Office of Transportation Technologies, other DOE offices, universities, and industries in advanced materials research. The Advanced Propulsion Laboratory provides a facility for testing new engine and combustion concepts.

- Electric utility R\&D involves work to improve the efficiency, reliability, and safety of the electric distribution system. Examples include integrated resource planning, high-temperature superconductor research, advanced distribution and transmission technologies, and electromagnetic field health effects. 


\section{Customers}

The major customers for the energy technology work include DOE, the Nuclear Regulatory Commission, other federal agencies, industry for whom and with whom new technologies are developed, and the American taxpayers.

\section{$\underline{\text { Metrics }}$}

As noted previously, the energy technology programs represent $\$ 170 \mathrm{M}$ in annual expenditures. In FY 1993, the approximate breakdown of energy R\&D activities is shown in the following table.

\begin{tabular}{cc}
\hline \hline Technology Area & FY 1993 Budget (\$M) \\
\hline Production Technologies & \\
Fusion & 31 \\
Fission & 41 \\
Biomass & 5 \\
Fossil & 72 \\
Other $\quad$ Subtotal-Production & 106 \\
End-Use Technologies & \\
Buildings Sector & \\
Industrial Sector & 10 \\
Transportation Sector & 10 \\
Other Subtotal-End Use & 26 \\
TOTAL-Energy R\&D & 64 \\
\hline
\end{tabular}

Another important metric is the extent of industry interaction and participation in the energy technology programs. Approximately 89 energy-related CRADAs with a combined value of nearly $\$ 90 \mathrm{M}$ have been approved. In addition, more than 130 patent applications for ORNL energy technologies have been filed, and 54 licenses of ORNL technology have been executed with private industry. 


\section{BIOLOGICAL AND ENVIRONMENTAL SCIENCES AND TECHNOLOGY}

\section{Description}

The core competency on biological and environmental sciences and technology embraces interdisciplinary research and technologies designed to understand and solve major environmental and health problems related to energy development, production, and utilization. It is anchored in a strong fundamental research program that is driven by the DOE mission and extends to applied programs in human and ecological risk analysis, biotechnology, regulatory analysis, and design and implementation of pollution prevention and environmental control and remediation technologies. Major participating ORNL divisions are Environmental Sciences, Biology, Chemical Technology, Health Sciences Research, and Energy. Additional support comes from the Engineering Physics and Mathematics, Chemical and Analytical Sciences, and Engineering Technology divisions. Environmental issues addressed include global climate change, nuclear and hazardous waste management, and environmental restoration of contaminated sites. Studies of life processes and development and application of biological approaches to meet national needs in health and environmental protection, medical diagnostics, pollution abatement, and energy production are also emphasized. ORNL projects increased participation in the burgeoning field of biotechnology and has positioned itself to be a national leader in assessment of biotechnological needs and development of novel designs. The diverse spectrum of interactive disciplinary foundations (biology, chemistry, engineering, physics, ecology, geology, hydrology, toxicology, computational sciences, and social sciences) for this core competency portrays the uniqueness of ORNL relative to other research institutions.

The multifaceted genome program includes development of mouse models of human genetic disorders and international dissemination of the genome program newsletter. Nuclear medicine focuses on both diagnostics and drug delivery. Structural/computational biology and protein engineering encompass structurefunction analyses of macromolecules and integrate these activities with the highperformance computing community. Environmental biotechnology extends from correlating molecular indicators of stress with ecosystem effects to the manipulation of microbial genomes to enhance the degradation of contaminants. Bioprocessing includes the underpinning $R \& D$ necessary for the utilization of microbes and biological materials for pollution abatement and biomass conversions.

Environmental research focuses on ecosystem theory, population modeling, biogeochemical cycling, environmental transport processes and modeling, subsurface science, effects of contaminants on ecological systems, landscape ecology, geohydrological analyses, environmental assessments, and ecological risk assessments. Outgrowth technologies include chemical and physical separations, waste form development and performance assessments, biodestruction of hazardous materials, bioprocessing, multimedia waste treatment, radiochemical processing, waste 
systems analysis, environmental instrumentation, environmental solution chemistry, and mixed-waste characterization.

\section{Integrated Capabilities}

The core competency on biological and environmental sciences and technology is characterized by numerous integrated capabilities that span basic and applied research in accordance with DOE mandates in biological and environmental arenas and that extend to well-established industrial and educational outreach programs. The integration of disciplines and perspectives occurs at many levels-within divisions, across ORNL, throughout the Oak Ridge Complex, and in concert with our regional partners, The University of Tennessee (UT) and the Tennessee Valley Authority (TVA). Studying and solving today's complex environmental and biological problems require an interdisciplinary approach, and ORNL is uniquely able to integrate basic and applied research capabilities rapidly with technology development experience to tackle national and global issues. Research divisions provide focused technical expertise, while the ORNL centers and programs (Centers for Global Environmental Studies, Risk Management, Computational Sciences, Biotechnology, Bioprocessing Research and Development, and Energy Efficiency and Renewable Energy Program) and affiliated centers in the complex (e.g., Centers for Environmental Technology and Waste Management, Hazardous Waste Remedial Actions Program, Oak Ridge Centers for Manufacturing Technology) help mobilize the breadth of expertise needed to address complex issues. The Joint Institute for Energy and Environment, the Center for Environmental Biotechnology, and the Division of Biological Sciences-all at UT - are key collaborators in environmental research and integrated assessment. Central to the ability to solve environmental and health problems are environmental data management expertise and information center networks for which ORNL has become a recognized international leader. Unique user facilities supporting this core competency include the National Environmental Research Park (NERP), Walker Branch Watershed, Global Change Field Research sites, Bioprocessing Research Facility (BRF), and the Neutron Scattering Research Facility (NSRF).

New directions are being forged by the ORNL Biotechnology Caucus with representation from nine research divisions and major programs. Projected user facilities include the Center for Biological Sciences (CBS), the Advanced Neutron Source (ANS), and the National Field Test Site Facility (NFTSF).

The professional staff of this core competency is fully engaged in ORNL educational programs. The ORNL Science Education and External Relations Office offers year-round learning and research opportunities for precollege, undergraduate, and graduate students. In addition, the Oak Ridge educational programs offer opportunities in postgraduate and faculty research. The UT-Oak Ridge Graduate School of Biomedical Sciences represents a 25-year unique partnership between ORNL's Biology Division and UT, which has resulted in the granting of 144 doctoral degrees based on research conducted at ORNL. Another ORNL-UT partnership, the 
University of Tennessee Graduate Program in Ecology, has provided training and research opportunities for students since 1969.

Special capabilities which comprise the biological and environmental sciences and technology core competency include:

- Mammalian Genetics and Genome Studies

- Informatics and Computational Biology

- Protein Engineering and Structural Biology

- Cancer Biology and Biomedical Technology

- Bioremediation, Bioprocessing, Biosensors, and Biomarkers

- Biomass Energy Systems

- Environmental, Ecological, and Health Risk Assessments

- Environmental Data Management Systems

- Ecosystem Theory, Ecological and Environmental Modeling

- Global Element Cycle Modeling

- Biogeochemical Cycling of Materials and Contaminants

- Effects of Contaminants and Other Stresses on the Environment

- Earth Sciences and Hydrology

- Environmental Site Characterization and Instrumentation

- Multimedia Waste Treatment Process and Equipment Development

- Radiochemical Processing

- Chemical and Physical Separations

- Environmental Sampling and Analysis

- Pollution Prevention

\section{Mission Support}

This core competency supports ORNL's stated missions to continue a broad interdisciplinary, cross-cutting program that addresses science and technology, energy resources, environmental quality, and industrial competitiveness. Concurrently, through its multifaceted educational and training programs, the core competency also plays a vital role in the career development of the nation's future leaders in science and technology.

This core competency supports the DOE missions in the areas of energy-related health effects, genome research, diversity in developing safer and more efficient energy sources leading to energy independence, in improving environmental quality, and in promoting economic competitiveness. 


\section{Examples}

End products derived from this core competency include:

- Expanded frontiers of knowledge

- Advanced analytical techniques, theory development, and experimental approaches to quantify environmental effects at scales ranging from local to regional, landscape, and global

- New methods to assess and mitigate environmental/health risks

- Biosensors and biomarkers for medical/environmental/industrial applications

- Mass spectrometry for molecular diagnostics and genome sequencing

- Novel biomedical products and radiopharmaceuticals

- Mouse models of human genetic disorders

- Genetically engineered organisms and proteins for applications in biotechnology

- Data bases for toxic substances, transgenic mice, genomes, environmental remediation, and global climate change

- Innovative and cost-effective environmental restoration technologies for remediating contaminated groundwater, surface water, and soils

- Technologies to prevent, minimize, separate, treat, immobilize, package, and dispose of radioactive, hazardous, and mixed wastes

- Technologies for decommissioning and decontaminating contaminated buildings, materials, and equipment

- Environmental transport models to allow predictions about the fate of contaminants in environmental media and novel detection systems for monitoring their migration

- Development of biofuel feedstocks and biomass for direct combustion

- Development of advanced bioprocessing systems for chemicals and fuels

- Innovative pollution prevention techniques

\section{Customers}

Sponsors and customers include the DOE Offices of Energy Research (including Basic Energy Sciences); Environmental Management; Environment, Safety, and Health; Policy; Energy Efficiency and Renewable Energy; and Technology Programs. Major local customers include the ORNL Waste Management and Remedial Action Division, the Martin Marietta Energy Systems (MMES) Environmental Restoration and Waste Management Organization, and other DOE sites such as Hanford and Fernald. Other federal agencies sponsoring research include the Federal Energy Regulatory Commission, Environmental Protection Agency (EPA), Department of Defense (DOD), National Aeronautics and Space Administration (NASA), National Institutes of Health (NIH), National Institute of Environmental Health Sciences, and the Centers for Disease Control and Prevention. Sources of private sector support include the Electric Power Research Institute and numerous pharmaceutical, manufacturing, chemical, and 
biotechnology companies. Sponsors and customers are attracted by our breadth and depth of expertise, ability to mobilize interdisciplinary teams, rapid deployment of basic research findings to applied solutions, availability of the Oak Ridge Reservation as a demonstration test bed, and opportunities offered for the training of students.

\section{Metrics}

Inclusive of approximately 400 scientists and engineers, ORNL administers one of the larger, more diversified biological/environmental ventures in the DOE network with an annual operating budget of about $\$ 156 \mathrm{M}$. The replacement cost of facilities for this core competency exceeds $\$ 400 \mathrm{M}$.

Products range from basic research publications to technical reports to environmental assessments and risk assessments for policy decisions. Scientists and engineers of this core competency publish about 800 articles (about half in peerreviewed journals) and book chapters annually. Collectively, this staff also gives more than 900 technical presentations each year, about one-third of which are invited. Additionally, 28 patents and licenses were recently secured. As an indication of the recognized merit of the programs, its researchers won four R\&D 100 Awards during the past four years. Numerous other prestigious awards, including membership in the National Academy of Sciences, have been won. Memberships to editorial boards, service to professional societies, and appointments to national advisory committees are also extensive.

Presently, 23 CRADAs have been established within this core competency, which also administers over 300 subcontracts to outside vendors (universities, private firms, and special consultants) in a typical year.

The user facilities of this core competency serve many external researchers each year. Unique research materials and computer programs are also provided to hundreds of investigators worldwide. About 700 guest scientists (students, postdoctoral investigators, and visiting faculty and industrial scientists) perform research in collaboration with the permanent staff annually. In addition, the Ecological Studies Center each year attracts 15,000-20,000 students from kindergarten through twelfth grade. 
This page intentionally left blank. 


\section{ADVANCED MATERIALS SYNTHESIS, PROCESSING, AND CHARACTERIZATION}

\section{Description}

ORNL is one of the largest performers of materials R\&D in the nation, with approximately 400 professionals engaged in a wide range of advanced materials programs related to ceramics and composites, metals and alloys, surfaces and thin films, polymers, superconductivity, and materials processing and characterization. These programs advance the materials frontier, provide materials underpinning for DOE technologies, develop and operate national research facilities, and form the basis for extensive industrial outreach. Distinguishing capabilities exist in many areas, including ceramics processing, alloy development, surface science and technology, neutron scattering, materials microanalysis, ion implantation, radiation effects, welding science, materials synthesis, thin-film processing, and computational materials science.

\section{Integrated Capabilities}

ORNL materials programs span the continuum from basic research through applications with emphasis on the synthesis, processing, and characterization of several important materials classes, including ceramics and composites, metals and alloys, superconductors, and thin films. All of these areas involve the integration of basic and applied research, unsurpassed characterization facilities, extensive synthesis and processing capabilities, and a strong DOE and industrial technology pull to address materials issues of national significance. Special capabilities which comprise the materials core competency include:

- High-Performance Structural Metallic and Intermetallic Alloys

- High-Performance Ceramics, Ceramic Composites, and Carbon-Based Materials

- Synthesis, Processing, and Joining of Advanced Materials

- Chemistry of Materials and Materials Processing

- Materials Characterization, Microanalysis, and Properties Evaluation

- Thin-Film Materials and Surface Ścience and Technology

- Ion Beam and Laser Processing

- Superconductivity

- Neutron Scattering

- Materials Theory, Process Modeling, and Computational Materials Science

- Engineered Materials for Energy Applications

- Radiation Effects

- Materials for Nuclear Technologies 


\section{Mission Support}

Materials $R \& D$ represent a key enabling technology which is critical to advances in many other technologies, including energy, transportation, manufacturing, health, and the environment. ORNL materials programs support DOE missions in basic science, facilities development and operation, energy efficiency and renewable energy, fossil energy, fusion energy, fission energy, education, and technology transfer.

\section{Examples}

Products supported by the competency include research publications and patents, technical data, new materials and materials research facilities, and technology transfer. Examples include:

- Intermetallic alloys (research on embrittlement mechanisms through commercialization of aluminides for high-temperature applications)

- Advanced ceramics (research on ceramics processing through the commercialization of gel casting for cost-effective fabrication of advanced ceramics; research on toughening mechanisms through the commercialization of whisker-toughened ceramics for cutting tools)

- Surface modification (ion implantation research through the commercial ization of wear-resistant prostheses)

- Neutron scattering (materials characterization through the development of polymer blends and welding technology)

- Alloy development (radiation effects research through development of radiation-resistant alloys for fission and fusion power)

- Thin films (basic interface and electrolyte research through the development of prototype thin-film batteries with industry; fundamental studies of laser and plasma processing through the development of advanced deposition technologies)

- Superconductivity (materials synthesis and characterization through conductor development with industry)

- Computational materials science (first-principles calculations of materials properties through simulations with industry of plasma processing, welding, polymer dynamics, microstructural development, and superplastic forming) 
- Materials characterization facilities (development of new characterization techniques through development and operation of national research facilities, including user facilities such as the High-Temperature Materials Laboratory, Neutron Scattering Research Facilities, Shared Research Equipment facilities, Surface Modification and Characterization laboratory, and the proposed Advanced Neutron Source)

\section{Customers}

Customers for the advanced materials competency include DOE program sponsors, related DOE technology offices, industry, universities, and the materials science community. Their needs are satisfied through research publications, access to unique facilities, development of new materials and processing technologies, and cooperative research agreements and licenses. Comparative advantages exist in the integration of basic R\&D activities with related technology programs, the availability of large and often unique research facilities, and the development of close relationships with industry.

\section{Metrics}

- ORNL has one of the largest materials R\&D programs in the nation with more than $\$ 130 \mathrm{M}$ in research expenditures annually.

- The replacement cost of ORNL materials R\&D facilities exceeds $\$ 1 B$.

- ORNL materials R\&D programs account for more than 700 technical publications annually, including 350 journal articles. ORNL materials researchers give more than 700 technical presentations each year, including 300 invited talks.

- ORNL materials R\&D user facilities serve approximately 300 outside researchers each year. More than 500 guest scientists and engineers perform research in ORNL materials divisions annually.

- ORNL materials R\&D programs account for approximately 65 CRADAs, 31 Superconductivity Partnership Program agreements, and 30 licenses with U.S. industry.

- ORNL educational programs in materials science reach over 3000 precollege students, 500 teachers, and 200 undergraduates and postgraduates each year.

- ORNL materials developments (including ion-implanted artificial prostheses, transmutation-doped silicon, and high-performance ceramics and alloys) have a private sector impact exceeding $\$ 300 \mathrm{M}$ per year. 
This page intentionally left blank. 


\section{NEUTRON-BASED SCIENCE AND TECHNOLOGY}

\section{Description}

The original scientific centerpiece of what was to become ORNL was the X-10 Graphite Reactor, which helped to establish a core competency in neutron-based science and technology from the earliest days of ORNL. This competency has grown and broadened over the past 50 years and has always been an essential part of the total capability at ORNL. It includes the design and operation of neutron sources (reactors and accelerators) and the use of neutrons in science and technology (neutron scattering, isotope production, neutron activation analysis, and materials irradiation). Many elements of this competency are unique: the High-Flux Isotope Reactor (HFIR) has the world's highest thermal neutron flux, the HFIR is the only source of heavy transuranic isotopes outside of Russia, the neutron activation analysis facility at HFIR is unique within DOE, and the Advanced Neutron Source (ANS) will be unsurpassed both in neutron flux and breadth of scientific and technological applications.

\section{Integrated Capabilities}

ORNL capabilities in neutron science and technology cover a broad spectrumbasic and applied research on the interaction of neutrons with nuclei and all forms of condensed matter, the development and use of techniques for the production of neutron-rich radioactive isotopes, calculations of neutron transport in complex systems, and design and operation of neutron sources. Integration of many capabilities is demonstrated in the operation of the HFIR, which produces neutrons for use in neutron scattering studies in a wide range of materials, for production of transuranic isotopes, for development of methods of producing other isotopes, for sensitive analytic measurements of trace elements, and for the study of radiation damage by neutrons in materials of technological importance. Another prime example of capability integration is the ANS project where a new research reactor of unprecedented flux and associated experimental facilities is being designed to meet a very challenging set of design criteria. Special capabilities which comprise the neutron-based science and technology core competency include:

- Neutron Scattering

- Isotope Production by Neutron Capture Reactions (including transuranic isotopes)

- Neutron Activation Analysis

- Neutron Irradiation of Materials

- Neutron Cross-Section Measurements

- Computer Simulation of Neutron Interactions and Transport

- Reactor Physics and Criticality Safety Computations

- Neutron Instrumentation Development (Detectors and Reactor Control Systems) 
- Reactor and Accelerator Operations

- Hot Cell Operations-Processing and Analysis of Radioactive Materials (including transuranic isotope separation)

- Separation of Stable Isotopes

- Design of Major Neutron Facilities (ANS)

- Physicochemical Characterization of Transuranics

\section{Mission Support}

Neutron science and technology support DOE and ORNL missions in the operation of major research facilities, materials and chemical sciences, energy production technologies, environmental restoration, energy efficiency, technology transfer, and education.

\section{Examples}

Products of this competency include research publications, technical data, special research materials, medical isotopes, analytical services, computer simulation codes, nuclear data libraries, and research facilities. Examples include:

- Neutron Scattering. Ten neutron spectrometers at HFIR are used for fundamental studies of the structure and dynamics of alloys, magnetic materials, superconductors, polymers, biological materials, and colloids. These facilities are used by an active in-house staff in addition to scientists from universities, industries, and other government laboratories. Special cooperative programs exist with Ames Laboratory and with the Japanese government. User programs exist in neutron scattering, smallangle neutron scattering, and neutron residual stress analysis.

- Transuranic Isotope Production. ORNL is the only source of heavy transuranic isotopes outside of Russia. These materials, produced in the HFIR and separated in the Radiochemical Engineering Development Center (REDC), are used in fundamental studies of the physics and chemistry of the transuranic elements and their compounds and in various applications using the unique properties of these materials. One of the most important products is $252 \mathrm{Cf}$, a spontaneous neutron source, which has many important applications including neutron radiography of aircraft by the U.S. Air Force and the successful treatment of cervical cancer.

- Other Isotopes. ORNL supplies the worldwide research community with 225 stable isotopes and has the only facility in the U.S. capable of producing these materials. In addition, techniques are developed in collaboration with radiopharmaceutical companies to produce new medical isotopes. 
- Neutron Activation Analysis. The neutron activation analysis facility at HFIR is unique within DOE, and the high thermal flux makes this one of the most sensitive analytic facilities in the world. This facility gained national attention in 1991 when it was used in analyses which showed that former president Zachary Taylor was not poisoned with arsenic. Recent work involved the analysis of 5000 soil samples for $\mathrm{Hg}$ content at a Superfund site, and work now in progress for the International Atomic Energy Agency will involve a search for fissile material in soil, water, and vegetation samples gathered worldwide as a part of the international nuclear nonproliferation program. Future work will include analysis of high-purity industrial materials (e.g., silica used for optical fibers).

- Materials Irradiation. The materials irradiation facilities at HFIR are used in a collaborative program with Japan to study materials of interest in the fusion energy program; no other facility in the U.S. could be used for these studies. The ANS project also uses the HFIR facilities for materials and fuel studies.

- Neutron Cross-Section Measurements. The Oak Ridge Electron Linear Accelerator produces pulsed neutron beams for nuclear cross-section measurements in the epithermal energy range. These data are important in fission technology and in fundamental nuclear physics.

- ANS. Initial construction funds for this project are in the President's budget for FY 1995. It will be the world's best neutron research center with a reactor producing beams with a thermal flux five times higher than any existing facility, hot and cold sources, extensive neutron scattering instrumentation, analytic capabilities, isotope production facilities, materials irradiation facilities, and the most powerful positron beams in the world. The HFIR and the High Flux Beam Reactor at Brookhaven are planned to be shut down when the ANS is operational.

\section{Customers}

Customers for this competency include DOE program sponsors in basic energy sciences, nuclear physics, fission and fusion energy production, energy efficiency, environmental and health protection, and waste remediation. Outside of DOE, customers include the national, industrial, and academic communities in materials, chemicals, nuclear power, pharmaceuticals, waste management, and the U.S. Air Force. Research facilities are used by advanced students as part of their education. 


\section{Metrics}

- ORNL has one of the largest neutron-based research programs in the world with approximately $\$ 118 \mathrm{M}$ in annual expenditures.

- The replacement cost of ORNL neutron facilities exceeds \$1.5B.

- HFIR operations.

\section{$\underline{\text { CY91 }} \quad \underline{\text { CY92 }} \quad \underline{\text { CY93 }} \quad \frac{\text { CY 94 }}{\text { (1 qtr) }}$}

Availability (\% of total annual time)

Operating

$64.7 \quad 63.1 \quad 48.9$

Planned outages

$25.2 \quad 25.4 \quad 15.0$

Unplanned outages

Unplanned shutdowns

$10.1 \quad 11.4 \quad 36.1$

Unplanned safety function actuations

$\begin{array}{lll}3 & 7 & 4\end{array}$

58.0

$0 \quad 5$

40

$5 \quad 1 \quad 0$

- Neutron scattering user operation. About 35,000 instrument hours are supplied to a group of about 100 users each year. This facility has the highest thermal neutron flux in the world.

- Sales of $252 \mathrm{Cf}$ in the commercial market average about $\$ 2 \mathrm{M}$ per year. In addition, there are 96 loan agreements in force with 63 institutions covering 232 neutron sources containing $170 \mathrm{mg}$ of $252 \mathrm{Cf}$.

- There are currently over 800 customers for isotopes produced at ORNL representing DOE laboratories, universities, and research and commercial institutions around the world.

- Isotope Enrichment Facility efforts have resulted in 31 patents and 1 R\&D 100 award.

- The Neutron Activation Analysis Program has gained acceptance by the Environmental Protection Agency for soil analysis.

- The ANS project has passed 39 reviews since January 1990. 
III. EMERGING CORE COMPETENCIES 
This page intentionally left blank. 


\section{OAK RIDGE MANUFACTURING TECHNOLOGIES}

\section{Description}

The Oak Ridge core competency in Manufacturing Technologies stems from the integration of complementary resources within ORNL, the Y-12 manufacturing plant, and the Center for Environmental Technology and Center for Environmental Restoration and Waste Management at K-25. Within this complex, the worldrenowned ORNL R\&D capabilities in materials and processes are meshed with the precision manufacturing, fabrication, and inspection skills of Y-12 and the state-ofthe-art environmental pollution prevention research and applications technologies centered at the $\mathrm{K}-25$ site. This combination of research, development, and manufacturing expertise has been combined with over $300,000 \mathrm{ft}^{2}$ of manufacturing space and over 1200 pieces of modern fabrication-related equipment to form the basis for the Oak Ridge Centers for Manufacturing Technology, which are physically located within the east end of the Y-12 Plant and in several operating divisions of ORNL. Over 20 industrially oriented centers, organized under 7 core technology areas, are in place and producing results to improve U.S. economic competitiveness. The seven core technology areas are Manufacturing Technology Deployment, Manufacturing Technology Demonstration, Manufacturing Technology Development, Energy and Environmentally Conscious Manufacturing, Manufacturing Quality and Process Assurance, Industry Specific Technologies, and Special Materials Processing. Centers include composites manufacturing technology, advanced ceramics, forming, coatings and finishing, metrology, photonics, diagnostic and process assurance, manufacturing skills campus, machine tool technology, joining, plating and cleaning, ultraprecision manufacturing, concurrent engineering, pollution prevention and energy conservation, and uranium and other radioactive materials processing.

Each center is organized with the technical expertise to promote immediate factory floor collaboration and training and the technology integration with industry to support prototypical testing, systems evaluation, and demonstration on a longer term basis. To assure that each center maintains its leading-edge technology capabilities for future industrial and government needs, approximately one-third of their base budgets are reserved for manufacturing technology R\&D. In addition, the emerging Manufacturing Technologies core competency is supported by scientific and engineering capabilities (e.g., materials science, materials and processing modeling, thermal and fluid flow analysis, design methods, and signal analysis).

Experience has shown that few research breakthroughs involve immediate transfer to industry without extensive investment and risks. The ability to deploy high-technology modeling and integration concepts to engineering designs and to fabricate proof-of-concept prototype hardware at affordable and environmentally benign costs provides a national resource to respond to new product innovations with reduced industrial risks. The Centers for Manufacturing Technology provide an ideal mechanism for such technology demonstrations. With a designation of 
"User Facility," industry researchers can actively participate in hands-on development of prototype products and/or new manufacturing systems development at minimal costs.

\section{Integrated Capabilities}

This emerging core competency encompasses capabilities in several important areas that meet the needs of U.S. manufacturing industries and the missions of the DOE.

- Information Infrastructure for Rapid/Flexible Realization

- Information management

- Simulation and modeling of products and processes

- Product design optimization (high yield/near net shape)

- Rapid prototyping and production simulation

- Product cost and analysis

- High-performance computing for robotics and intelligent systems processing controls

- Manufacturing Processes

- Integration of advanced materials and processes

- Mechanical process improvements

- Chemical process improvements

- Micro- and nanofabrication

- Simulation for flexible production

- Operations for optimization and integration demonstrations

- Proof of processibility

- Environmentally conscious manufacturing

- Manufacturing Equipment and Systems

- High-precision machining and forming equipment

- Joining and coating devices/systems

- Robotics and intelligent machines

- Advanced sensors and controls

- In-process sensors and digital signal processing controls

- Chaotic systems analysis

- Fuzzy logic controls

- Process systems integration

- Energy conservation

- Quality Realization/Assurance

- Physical/chemical testing and evaluation

- Systems/component diagnostics

- Failure avoidance

- Standards/benchmarking 


\section{Mission Support}

This core competency fully supports the DOE mission through partnerships that contribute to U.S. industrial competitiveness while maintaining a strong science and technology base. The Oak Ridge complex, including the defense manufacturing facilities at Y-12, ORNL, and the Centers for Manufacturing Technology, provides a unique DOE facility integration which ranges from basic research in materials and processes to production-scale metal coating, forming, machining, finishing, and inspection of complex assembly products. The rapid deployment of this expertise to industry supports the central DOE themes of efficient energy production, utilization, distribution, and conservation that is environmentally responsive and safe. Through the Centers for Manufacturing Technology and the Oak Ridge User Centers, industrial partners have proven that the application of DOE technologies and manufacturing concepts to their present processing problems can enhance their productivity, assure higher quality at an affordable cost, and ameliorate environmental impacts of their operations. Strengthening industry in this manner results in high-value jobs in industry and in the upgrade of DOE processes as well.

\section{Examples}

End products from the emerging Manufacturing Technologies core competency cross cut most major industrial markets. Activities include:

- Development and demonstration of information infrastructures for rapid product realization, including information management, simulation and modeling of products and processes, virtual product design, and rapid prototyping.

- Demonstration and deployment of manufacturing processes which incorporate the integration of advanced materials, mechanical and chemical process improvements, and the design and fabrication of micro- and nanocomponents/systems.

- Development and demonstration of production equipment and processing systems which are beneficial to industry, including high-precision CAD/CAM machines with error compensation, in-line metrology, robotics, and intelligent systems for process automation and advanced process-integrated sensors and controllers.

- Development and demonstration of pollution prevention technologies which result in establishing environmentally conscious manufacturing practices. The technologies would be based on total life-cycle accountability models, recycling processes, scrap minimization, energy-efficient and material conservation considerations, emissions control and detection, and risk management assessment. 
- Through the Oak Ridge Science Education Center, the Centers for Manufacturing Technology, the User Centers, and Y-12 plant manufacturing training and education facility, assistance is available to industry to upgrade the skills and basic knowledge of their work force. Emphasis is placed on necessary present-day skills, as well as training for hightechnology manufacturing, including robotics, sensors, controls, and advanced computing and computer simulations.

The Oak Ridge Manufacturing Technologies emerging core competency also includes a significant outreach activity with particular focus on regional small businesses. This effort, which encompasses all manufacturing technologies, has received high praise from the Secretary of Energy and serves as a model for other installations.

\section{Customers}

Efforts that constitute the Oak Ridge emerging core competency in manufacturing technologies are being executed in several divisions at ORNL and at the Oak Ridge Centers for Manufacturing Technology. Current customers include the Department of Energy (Energy Research, Environmental Management, Energy Efficiency and Renewable Energy, and Defense Programs); the Department of Commerce; DOD (including the U.S. Army, U.S. Navy, and U.S. Air Force); a variety of U.S. industrial companies representing the electronics industry (including SEMATECH); the electric motor and components industry; the U.S. optics industry, U.S. automobile industries, U.S. defense industries; the U.S. textile industry (AMTEX Partnership); and the biomedical and health care industries.

\section{Metrics}

Comparison With Other DOE Laboratories. In general, all the DOE Laboratories have varying degrees of basic materials and processing technologies. However, the Oak Ridge complex is unique in its combination of world-renowned materials and processing R\&D with over 50 years of precision manufacturing fabrication, inspection, and metrology experience of complex parts and assemblies.

Oak Ridge Facilities Which Support the Manufacturing Technologies Emerging Core Competency.

- Oak Ridge Centers for Manufacturing Technology

- Oak Ridge User Centers for Manufacturing Technology

- Bioprocessing Research and Development Center

- Center for Engineering Systems Advanced Research

- High-Temperature Materials Laboratory

- Ceramic Manufacturability Center 
- Gear Metrology Center

- Oak Ridge Center for Healthcare Industry Development

\section{Quality Effectiveness.}

- Outreach Program: In FY 1993 and FY 1994, there were 1306 instances of problems solved and requests for assistance and information met. Requests for information and/or assistance have come from 48 of the 50 U.S. states (no requests from Montana or North Dakota). California (223), Tennessee (529), Ohio (130), Pennsylvania (99), and Michigan (98) account for the majority of the requests.

- A customer satisfaction survey was mailed to each 1993 Outreach Program participant. Over $90 \%$ of the responding customers indicated that useful information was provided, and $98 \%$ indicated they would use the program again and/or recommend our service to others. Fiscal benefits were reported by $55 \%$ of the respondents, and $21 \%$ indicated that jobs were either created or retained as a result of the Outreach Program. In addition, a large percentage (77\%) of the respondents reported a positive product quality improvement.

- The Outreach Program is continuing to grow. Three additional states (Florida, Georgia, and North Carolina) have signed assistance agreements with the program.

CRADAs. Another metric is the successful use of CRADAs to transfer technology to industry. Approximately three-quarters of all Oak Ridge CRADAs have a manufacturing component. Funding for these projects ranges from the $\$ 10 \mathrm{~K}$ level to multimillion dollar activities. No particular industrial sector appears to dominate. Programs range from precision mirror fabrication, powder processing, and inorganic membrane development to machine tool evaluation and machining operations development.

Navy Best Manufacturing Practices. In March 1993, Oak Ridge participated in a survey conducted by the Navy's Best Manufacturing Practices Program Office. The survey team was comprised of 22 technical experts from various DOD facilities, NASA, and the National Institute for Standards and Technology. A total of 112 topics were reviewed, and of those, 77 were selected as "best practices." While this designation does not necessarily mean that a technology practiced at MMES is the very best of its type, it does provide an informal benchmark based on the 1254 practices that were reviewed during 54 surveys performed prior to the MMES survey. When a technology is selected as a best practice, it means that it is at least as good as similar practices previously observed by the survey teams and that it possesses unique characteristics not found elsewhere. 
This page intentionally left blank. 


\section{COMPUTATIONAL SCIENCE AND ADVANCED COMPUTING}

\section{Description}

Leadership in the area of computational science and advanced computing involves the capability to apply and extend advanced mathematical and computational techniques, information/data management and analysis methods, software tools, communications technologies, and high-performance computing systems and peripherals to solve important problems in science and engineering.

ORNL has long been a leader in computational plasma physics and materials science, nuclear physics and transport calculations, matrix computations, geographic information systems, and management of environmental information. More recently, ORNL has developed leadership positions in algorithms for parallel computers, informatics with emphasis on biosciences, global climate simulations, groundwater contaminant transport, distributed computing tools and interfaces, high-performance parallel computers, and data storage systems. As a result of this leadership, ORNL is heavily involved with major universities and with both computer and applications industries in collaborative research projects and commercialization activities.

\section{Integrated Capabilities}

ORNL computational programs integrate strong expertise in basic and applied research with outstanding high-performance computing systems and infrastructure. ORNL's core capabilities in this integration range from the ability to develop realistic mathematical models of complex phenomena and scalable algorithms for their solution to the availability of massively parallel processors and storage systems accessed by high-performance computing environments. Specifically, the integrated core capabilities are:

- Realistic Mathematical Models of Complex Phenomena

- Advanced Algorithms

- Software Components and Tools

- High-Performance Computing Systems

- High-Performance and High-Capacity Data Storage Systems

- Data Storage, Retrieval, and Analysis Tools

- Visualization Technologies

- Local- and Wide-Area High-Performance Networks

- Computer Architecture and Performance Evaluation 


\section{Mission Support}

High-speed, large-scale computation has become the primary enabling technology for advanced research in many areas of science and engineering. In many applications of direct interest to DOE and ORNL, computer simulations are the only feasible method of scientific investigation because of such factors as excessive cost for experimental facilities, modeling subatomic particles, and time domains spanning multiple decades. In addition, the findings of a number of blue-ribbon panels studying U.S. technological competitiveness have emphasized the critical importance of maintaining and extending the nation's traditional lead in the development and use of high-performance computing technology. Thus, competency in computational science and advanced computing supports DOE's R\&D mission and the nation's technological competitiveness.

\section{Examples}

Products supported by this emerging core competency include sophisticated models of complex phenomena, scalable high-performance computer software, advanced computing centers, performance analysis and understanding of new computer architectures, research publications, and technology transfer. Examples include:

- Center for Computational Sciences (CCS) with one of the world's most powerful supercomputers

- GRAIL pattern recognition system for recognizing genes in DNA sequence strings with automatic remote processing of sequences using electronic mail

- Global climate model incorporating latest physics and numerical techniques for extended-term climate simulations, both historical for calibration and future for promotion of understanding and aid in decision making

- Parallel Virtual Machine (PVM) software to enable networked computers (including workstations) to function as a single computing resource

- Groundwater flow and transport code incorporating all major characteristics and phenomena necessary for realistic and accurate simulations of groundwater preservation, contamination, and remediation

- Multidimensional software, stochastic and deterministic, for nuclear design and safety analyses in use on a worldwide basis 
- Data storage and retrieval resources and locator tools associated with DOE's Atmospheric Radiation Measurements Archive, NASA's Earth Observing System, and ORNL's CCS for fast access by scientists and policy makers

- sca-LAPACK software library of scalable algorithms for solving many of the common scientific matrix problems on a range of parallel computers

- Industrial interactions utilizing LS-DYNA, a local parallel version of a materials dynamics code, to solve problems involving automobile crashes

\section{Customers}

Customers for this emerging core competency span almost all industries and government agencies. Some examples are power utilities, gas and oil companies, waste remediation industries, automotive companies, educational institutions, textile companies, DOE (Energy Research, Defense Programs, Energy Efficiency and Renewable Energy, Nuclear Energy), NASA, NIH, EPA, NRC, and the defense industry and agencies.

\section{Metrics}

As determined by one independent source, ORNL essentially will be tied with Los Alamos National Laboratory as the third most powerful computing site in the world, behind Japan's National Aerospace Lab and USA's National Computing Security Center, when the procured Intel Paragon XP/S-150 arrives in late FY 1994.

Some other examples of metrics include the following:

- Scientific knowledge includes approximately 400 peer-reviewed journal papers published per year and 100 major invited presentations per year.

- Current data storage capacity of 5 terabytes under upgrade to a funded capacity of over 100 terabytes by early FY 1995 substantiates ORNL as one of the leaders in data storage and retrieval.

- ORNL has been selected as a data storage and retrieval site by NASA's Earth Orbiting Satellite Program (1 of 8 and the only DOE site) and by the DOE Atmospheric Radiation Measurement Program (the only longterm storage site) - the latter program based at DOE's Pacific Northwest. Laboratory. 
- ORNL is an international leader in scalable algorithms for basic computations on parallel computers through the development of LAPACK and scaLAPACK, used by over 800 computational scientists and computer vendors worldwide.

- LINPACK, a precursor to LAPACK, is used by all computer vendors and buyers as an internationally accepted benchmark of a computer's performance on scientific computing tasks.

- Application codes [e.g., HITC (1991 Gordon Bell Prize), SCALE (over 600 copies distributed), DORT and TORT (over 500 copies distributed), and HEATING (over 150 copies distributed)] developed at ORNL have received international recognition and usage.

- ORNL receives more than $\$ 5 \mathrm{M}$ per year from industry and through CRADAs in support of research directly linked with high-performance computing capabilities. 
IV. INSTITUTIONAL COMPETENCIES 
This page intentionally left blank. 


\section{DEVELOPMENT AND OPERATION OF NATIONAL RESEARCH FACILITIES}

\section{Description}

ORNL is the home of 14 sophisticated experimental science facilities that are available to users nationwide and, in most cases, throughout the world. Ten are officially designated by the DOE as "user facilities." These research facilities serve scientists and engineers from universities, industries, and other government laboratories, as well as ORNL staff. They simultaneously contribute to DOE missions and other national R\&D goals by minimizing unnecessary duplication of effort, promoting beneficial scientific interactions, and making the most effective use of costly and, in many cases, unique equipment.

\section{Integrated Capabilities}

The development and operation of these facilities require the broad interdisciplinary human and technical resources available at ORNL. They are supported by specific elements of the research infrastructure ranging from atomic physics to genetics and by operational expertise relevant to a very wide range of scientific enterprises from research reactors to particle accelerators to bioprocessors to extensive environmental research reserves. At various stages of a facility's lifetime, expertise in design, engineering, project management, computing/data acquisition, and instrumentation, as well as resources to support user services and an administrative infrastructure, are required.

\section{Mission Support}

These facilities support DOE missions in basic energy sciences, nuclear physics, advanced materials development, biotechnology, genetics, environmental science and technology, and energy efficiency. There is also a strong educational benefit; many graduate students use these facilities in their thesis research, and interactions are increasing with school teachers and K-12 students. Direct support for industrial. competitiveness is particularly evident in those facilities with a substantial fraction of industrial users.

\section{Examples}

- Atomic Physics EN Tandem Accelerator. This is a 7-MV tandem Van de Graaff machine used to study high-energy ion collisions with gases, solids, and electrons. Ion beams of most species through bromine and selected heavier ions are available for use at the accelerator. 
- Bioprocessing Research Facility. This facility has laboratories for investigations of advanced bioprocessing concepts using stirred-tank and columnar bioreactors and a fermentation pilot plant for large-scale experiments.

- Buildings Technology Center. This center provides the U.S. buildings industry with easy access to a unique collection of testing and analysis capabilities. Included is the Large-Scale Climate Simulator, which provides the roofing industry with a new capability for controlled testing of whole roof sections under dynamic conditions.

- High-Temperature Materials Laboratory (HTML). The HTML is actually six user centers, each devoted to a specific area of research in materials science-materials analysis, high-temperature $x$-ray diffraction, physical properties, mechanical properties, ceramic specimen preparation, and residual stress mapping. State-of-the-art instrumentation is made available to outside users in each of these research areas.

- Holifield Radioactive Ion Beam Facility. This facility consists of a 25-MV electrostatic accelerator and the Oak Ridge Isochronous Cyclotron, which serves as a booster. The facility is undergoing a major modification whereby it will be able to provide, in addition to beams of stable isotopes, radioactive ion beams with energies and species unobtainable elsewhere in the world.

- National Environmental Research Park. This facility provides 12,400 acres of protected land for research and education in the environmental sciences. The research park is an outdoor laboratory and has field research sites on which are located maintenance and support facilities sufficient to permit sophisticated and well-instrumented environmental experiments.

- Neutron Scattering Research Facilities. These facilities use intense neutron beams produced by the HFIR for fundamental studies of the structure and dynamics of matter. Elastic, inelastic, and small-angle scattering instruments are used for research in solid state physics, chemistry, polymer science, biology, and materials science.

- Oak Ridge Electron Linear Accelerator. This facility produces intense nanosecond pulses of neutrons for measuring the interaction of neutrons with nuclei over a very broad energy range. Time-of-flight spectroscopy using a variety of detectors and flight paths allow cross-section measurements for energies from millivolts to over $50 \mathrm{MeV}$. 
- Shared Research Equipment Program. This facility offers state-of-the-art capabilities in the areas of transmission electron microscopy, atom probe field-ion microscopy, surface analysis, nuclear microanalysis, and mechanical properties microanalysis.

- Surface Modification and Characterization Research Center. Particle accelerators produce ion beams that can be used to alter the physical, electrical, or chemical properties of the near-surface region of solids and to create unique materials not possible to obtain with conventional equilibrium processing techniques.

- HFIR. The HFIR is an 85-MW, Be-reflected, light water-cooled reactor with the highest thermal neutron flux in the world. It has both in-core and neutron beam facilities and is used for the production of isotopes for medical, industrial, and research applications, as well as for materials irradiations, neutron activation, and neutron scattering studies.

- Center for Computational Sciences. This facility, one of the two DOE High-Performance Computing Research Centers, contains state-of-theart massively parallel processing (MPP) resources for Grand Challenge computing and correspondingly large data storage and networking capabilities. It is used both to enhance MPP computing capabilities, as well as to expand the application of this resource by a variety of user groups, particularly U.S. industries. This facility is anchored by an Intel Paragon XP/S-150, one of the world's most powerful supercomputers.

- Mammalian Genetics Facility. This ORNL facility has the largest collection of mouse mutants in the world for research purposes, with a capacity of over 250,000 mice, and it contains over 800 mutant mouse strains. Because of the physical similarities between mouse and human chromosomes, investigations of the mouse genome can be applied to humans as well. Breeding stocks of specific mutants have been provided to hundreds of laboratories worldwide.

- ANS. The ANS will be the world's best neutron research center with a reactor producing beams with a thermal flux five times higher than any existing facility, hot and cold sources, extensive neutron scattering instrumentation, analytic capabilities, isotope production facilities, materials irradiation facilities, and the most powerful positron beams in the world.

\section{Customers}

Customers for these facilities include the DOE program sponsors and related offices and the various user communities from universities, industries, other government agencies, and ORNL itself. Their needs are satisfied by providing reli- 
able, easy access to unique facilities; by providing cost-effective, safe, and efficient operation of facilities; by minimizing the environmental impact of facility operations; by providing appropriate support to users; by providing appropriate mechanisms to ensure the quality of the experimental programs that are carried out; and by improving facility performance.

\section{Metrics}

- ORNL has 10 designated DOE User Facilities, with significant collaboration at another, the Centers for Manufacturing Technology at the Oak Ridge Y-12 complex. This is more than any other multiprogram laboratory.

- The total funding for the Development and Operation of National Research Facilities competency was $\$ 120$ M in FY 1993. This included \$20M for the ANS Project.

- The replacement value of ORNL "user" facilities exceeds \$2B.

- Approximately 760 experimenters from 230 organizations performed research at these facilities in FY 1993.

- User profile: ORNL

$35.6 \%$

Other Government $\quad 9.1 \%$

University

Industry

$32.2 \%$

Foreign

$13.3 \%$

$9.8 \%$ 


\section{R\&D INTEGRATION AND PARTNERSHIPS}

The integration of basic research and development (R\&D) activities at ORNL and the establishment of partnerships with universities, industry, and other government laboratories offer significant opportunities to leverage and broaden the $R \& D$ programs at the Laboratory. $R \& D$ integration is achieved through coordinated program planning, co-location of basic and applied programs within research divisions, and interdisciplinary teaming in mission areas. Each ORNL core competency represents an integration of as many as a dozen major $R \& D$ programs ranging from basic research through applications and technology transfer. R\&D program integration within competencies and research divisions is reflected in the funding profiles shown in the appendices. Many examples of the successful integration of basic and development programs to execute Laboratory missions are summarized in the core competency descriptions in Section II. This is a major strength of ORNL and the DOE laboratories.

R\&D partnerships with universities, industry, and other government laboratories strengthen and extend Laboratory programs while making more efficient use of $R \& D$ resources and facilities. These partnerships include research collaborations, guest scientists and personnel exchanges, shared access to unique facilities, cooperative agreements with industry, and special relationships with other DOE facilities, The University of Tennessee, the Tennessee Valley Authority, and other institutions. These has been a significant increase in R\&D partnerships at ORNL in recent years. Approximately 35\% of ORNL research publications now include authors from other institutions, up from $20 \%$ five years ago. The number of guest scientists who perform research at the Laboratory has nearly doubled in 5 years and now includes more than 2000 university and 1500 industry researchers annually. More than 130 CRADAs have been executed since 1990 representing $\$ 170 \mathrm{M}$ in cooperative research with industry.

ORNL is unique in its proximity to DOE production and environmental restoration facilities in Oak Ridge. The Y-12 Plant, a world-class precision manufacturing center, and K-25 Site, a comprehensive environmental restoration activity, offer many opportunities for partnerships in the development and application of manufacturing and environmental technologies. The Oak Ridge Centers for Manufacturing Technology and Center for Environmental Technology are examples of R\&D partnerships with these facilities. R\&D partnerships are also maintained with many universities, including minority educational institutions, through subcontracting and research interactions. ORNL maintains particularly close ties with The University of Tennessee at Knoxville. Extensive cooperative arrangements such as the ORNL/UT Science Alliance include more than $100 \mathrm{UT}$ faculty and graduate students who perform research at ORNL. 


\section{Metrics}

- Number of research papers published jointly with other institutions.

- Number of guest scientists from universities and industry (2119 and 1557, respectively, in FY 1993)

- Value of R\&D subcontracts to universities (\$27M in FY 1993)

- Number of CRADAs (136 since 1990) 


\section{TECHNOLOGY TRANSFER}

ORNL has one of the most successful technology transfer programs in the DOE system. The Oak Ridge program leads the DOE complex in licensing and licensing revenues, is among the best in number of CRADAs, and leads the complex in industrial outreach. Since 1990, ORNL has established 136 CRADAs with a total value of $\$ 170 \mathrm{M}$. ORNL has also executed 83 licenses since 1985 , resulting in $\$ 80 \mathrm{M}$ in sales and generating $\$ 2 \mathrm{M}$ in royalties for use in technology transfer activities. Sales of licensed products have increased by $35 \%$ in each of the past three years. Patent applications have more than tripled in the past 5 years and are approaching 100 per year.

The Oak Ridge technology transfer program is a central function of Martin Marietta Energy Systems (MMES), management and operating contractor for ORNL, the Oak Ridge Y-12 Plant, and the Oak Ridge K-25 Site. The program is managed by the Office of Technology Transfer (OTT) which provides business support for licensing activities, CRADA negotiations, and patent applications. OTT is also responsible for MMES involvement in regional economic development activities. ORNL maintains a Partnership Office which is responsible for the Laboratory's technology transfer activities and provides a liaison to OTT. Working with OTT, ORNL was the first DOE laboratory to execute a license agreement with industry and the first to implement a CRADA.

MMES and ORNL have also contributed to the development of many innovative programs to stimulate regional economic growth including the Tennessee Innovation Center (a regional economic development enterprise), the Centers for Manufacturing Technology (a partnership with $Y-12$ which provided technical assistance to more than 600 companies in 1993), and the Minority-Owned Business Technology Transfer Consortium (a model within DOE). Including the impact of product sales from licensing of Oak Ridge technologies, these economic development activities have fostered the creation of more than 55 businesses and 3000 private sector jobs since 1985. MMES also provides leadership in many regional planning and development activities. For example, an ORNL staff member is currently on assignment as scientific liaison for the Tennessee Office of Economic and Community Development.

\section{Metrics (ORNL specific)}

- Number of CRADAs executed (136 since 1990)

- Average time to execute a CRADA (108 days for the past 6 months)

- Number of licenses of DOE technologies (83 since 1985)

- Sales of licensed products (\$80M since 1985)

- Licensing revenues (\$2M since 1985)

- Patent applications (62 through May for FY 1994) 
This page intentionally left blank. 


\section{SCIENCE EDUCATION}

The ORNL Science Education and External Relations Office provides comprehensive educational outreach programs to improve the quality of science and mathematics teaching, increase the size and diversity of the educational pipeline in these fields, and increase the future availability of people with scientific and technical skills. Inquiry-based, hands-on learning experiences are offered to precollege students, precollege teachers, undergraduates, graduate students, and postgraduates. More than 30 programs reach more than 20,000 precollege students and 800 teachers annually. Additional programs serve more than 1200 university students, faculty, and postgraduates each year.

The Office includes educational outreach partnerships with other agencies (e.g., the Appalachian Regional Commission), area schools, colleges, universities, and the private sector. ORNL's Oak Ridge Educational Network (OREN) provides an extensive educational telecommunications network that links schools and individuals to the greater Internet system. Programs such as the Ecological and Physical Sciences Study Center, Saturday Academy of Computing and Mathematics, Summer Science Outreach, Regional Science Bowls, and DOE Teacher Research Associates focus on precollege students and teachers. Internships, postgraduate research programs, and faculty research participation programs enhance undergraduate and graduate education.

Two University of Tennessee graduate schools are located at ORNL, the Oak Ridge Graduate School of Biomedical Sciences and the Graduate Program in Ecology. ORNL-UT programs such as the Science Alliance, Distinguished Scientist Program, and Collaborating Scientist Program promote extensive research interactions between the institutions and enhance undergraduate and graduate education.

Equity and diversity are a high priority in ORNL educational programs. Partnerships have been established with many minority educational institutions, including more than 20 research and development subcontracts with Historically Black Colleges and Universities representing commitments of more than $\$ 6 \mathrm{M}$. ORNL educational outreach programs served more than 2200 minority and 11,000 female precollege students, 386 minority and 539 female precollege teachers, and more than 400 minority and 375 female college students and faculty in FY 1993.

\section{Metrics}

- Participation in education programs

- Minority and women participation in education programs

- Subcontracts to minority education institutions 
This page intentionally left blank. 


\section{APPENDICES}

\section{A. COMPETENCY FUNDING BY ORNL PROGRAM \\ B. COMPETENCY FUNDING BY ORNL DIVISION/ OFFICE \\ C. PROGRAM FUNDING BY ORNL DIVISION/ OFFICE}


This page intentionally left blank. 


\section{Appendix A. Competency Funding by ORNL Program (FY 1993 Operating Costs)}

\begin{tabular}{|c|c|c|c|c|c|c|c|}
\hline Program & $\begin{array}{l}\text { Energy Production \& } \\
\text { End-Use } \\
\text { Technologies }\end{array}$ & $\begin{array}{c}\text { Biological and } \\
\text { Environmental } \\
\text { Sciences \& } \\
\text { Technology }\end{array}$ & $\begin{array}{c}\text { Advanced } \\
\text { Materials } \\
\text { Synthesis, } \\
\text { Processing, \& } \\
\text { Characterization }\end{array}$ & $\begin{array}{l}\text { Neutron-Based } \\
\text { Science \& } \\
\text { Technology }\end{array}$ & $\begin{array}{c}\text { Manufacturing } \\
\text { Technologies }\end{array}$ & $\begin{array}{l}\text { Computational } \\
\text { Science \& } \\
\text { Advanced } \\
\text { Computing }\end{array}$ & $\begin{array}{c}\text { Development \& } \\
\text { Operation of } \\
\text { National } \\
\text { Research } \\
\text { Facilities } \\
\end{array}$ \\
\hline Basic Energy Sciences & 12.1 & 4.8 & 53.7 & 66.4 & 2.1 & 14.9 & 66.7 \\
\hline $\begin{array}{l}\text { High Energy \& } \\
\text { Nuclear Physics }\end{array}$ & 1.3 & $\cdot$ & & 2.8 & & & 12.3 \\
\hline $\begin{array}{l}\text { Biological \& } \\
\text { Environmental } \\
\text { Research }\end{array}$ & & 24.8 & & 0.1 & & 2.4 & 4.2 \\
\hline Magnetic Fusion & 26.7 & 0.1 & 4.2 & 4.3 & 0.9 & 8.1 & 2.3 \\
\hline Energy Efficiency & 40.0 & 2.1 & 23.4 & 0.3 & 2.7 & 1.5 & 7.0 \\
\hline Nuclear Energy & 18.6 & 0.2 & 13.2 & 9.4 & 5.0 & 1.5 & 3.1 \\
\hline Fossil & 5.1 & 1.7 & 3.0 & 0.1 & & & 0.2 \\
\hline ERWM & 0.3 & 72.0 & 0.1 & 0.3 & 0.1 & 0.4 & \\
\hline Defense Activities & 2.5 & 0.3 & 0.1 & 12.4 & 8.4 & 0.7 & 4.0 \\
\hline - LDRD & 0.4 & 2.3 & 2.5 & 0.6 & 0.9 & 0.2 & 1.2 \\
\hline Technology Transfer & 3.4 & 0.8 & 5.1 & 0.2 & 3.3 & 1.7 & \\
\hline Other DOE & 6.0 & 16.2 & 3.1 & 8.8 & 9.9 & 5.3 & 6.9 \\
\hline NRC & 15.4 & & 3.6 & 1.6 & & 5.6 & \\
\hline DOD & 5.4 & 8.0 & 3.0 & 5.0 & 9.8 & 3.1 & 5.0 \\
\hline $\begin{array}{l}\text { Other Federal } \\
\text { Agencies }\end{array}$ & 8.0 & 8.0 & 6.0 & 5.5 & 3.9 & 3.9 & \\
\hline Other & 2.6 & 3.4 & 0.9 & 0.1 & 3.4 & 1.4 & 4.0 \\
\hline Offsite Subcontracts & 21.3 & 15.9 & 15.5 & 0.5 & 1.0 & 4.7 & 3.1 \\
\hline TOTALS & 169.1 & 160.6 & 137.4 & 118.4 & 51.4 & 55.4 & 120.0 \\
\hline
\end{tabular}


This page intentionally left blank. 


\section{Appendix B. Competency Funding by ORNL Division/Office (FY 1993 Operating Costs)}

\begin{tabular}{|c|c|c|c|c|c|c|c|}
\hline Division/Office & $\begin{array}{c}\text { Energy Production } \\
\text { \& End-Use } \\
\text { Technologies }\end{array}$ & $\begin{array}{c}\text { Biological and } \\
\text { Environmental } \\
\text { Sciences \& } \\
\text { Technology }\end{array}$ & $\begin{array}{c}\text { Advanced } \\
\text { Materials } \\
\text { Synthesis, } \\
\text { Processing, \& } \\
\text { Characterization }\end{array}$ & $\begin{array}{c}\text { Neutron-Based } \\
\text { Science \& } \\
\text { Technology }\end{array}$ & $\begin{array}{l}\text { Manufacturing } \\
\text { Technologies }\end{array}$ & $\begin{array}{c}\text { Computational } \\
\text { Science \& } \\
\text { Advanced } \\
\text { Computing }\end{array}$ & $\begin{array}{c}\text { Development \& } \\
\text { Operation of } \\
\text { National Research } \\
\text { Facilities }\end{array}$ \\
\hline Analytical Chemistry & 5.2 & 9.5 & 0.1 & 0.5 & 0.2 & & \\
\hline $\begin{array}{l}\text { Advanced Neutron } \\
\text { Source } \\
\end{array}$ & & & & 20.4 & & & 20.4 \\
\hline Biology & & 12.8 & & 0.4 & & 0.2 & 3.0 \\
\hline $\begin{array}{c}\text { Center for } \\
\text { Computational } \\
\text { Science }\end{array}$ & 0.6 & 3.9 & 1.5 & & 0.6 & 8.1 & 7.1 \\
\hline $\begin{array}{l}\text { Chemical } \\
\text { Technology }\end{array}$ & 6.9 & 37.6 & 1.0 & 27.2 & 1.0 & 1.0 & 5.5 \\
\hline Chemistry & 5.5 & 2.7 & 3.2 & 1.6 & & 0.8 & \\
\hline $\begin{array}{l}\text { Computing } \\
\text { Applications } \\
\end{array}$ & & 1.0 & & 3.5 & & 0.3 & \\
\hline Energy & 14.4 & 2.3 & 0.7 & & 0.2 & 3.7 & 2.0 \\
\hline $\begin{array}{l}\text { Engineering Physics } \\
\text { \& Mathematics }\end{array}$ & 4.8 & 2.2 & 0.2 & 4.1 & 0.4 & 11.1 & 5.4 \\
\hline $\begin{array}{l}\text { Engineering } \\
\text { Technology }\end{array}$ & 18.8 & 6.7 & 5.7 & 6.5 & 17.6 & 6.5 & 12.2 \\
\hline $\begin{array}{c}\text { Environmental } \\
\text { Sciences }\end{array}$ & 2.3 & 33.2 & & & & & \\
\hline Fusion Energy & 22.1 & 1.4 & 1.6 & 0.3 & 3.2 & 7.9 & 2.1 \\
\hline $\begin{array}{c}\text { Health Sciences } \\
\text { Research }\end{array}$ & 0.8 & 22.4 & & & & 0.1 & \\
\hline $\begin{array}{c}\text { Instrumentation \& } \\
\text { Controls } \\
\end{array}$ & 4.0 & 2.0 & 1.0 & 1.0 & 11.0 & 4.0 & 7.0 \\
\hline Metals \& Ceramics & 52.2 & 1.7 & 59.3 & 18.7 & 13.1 & 3.4 & 6.5 \\
\hline Physics & 1.6 & & & & & 0.7 & 11.4 \\
\hline $\begin{array}{c}\text { Robotics \& Process } \\
\text { Systems } \\
\end{array}$ & 6.0 & 6.0 & & & 3.0 & 1.0 & 1.0 \\
\hline Research Reactors & & & 30.3 & 30.3 & & & 30.3 \\
\hline Science Education & 0.1 & 0.3 & 0.3 & 0.1 & 0.1 & 0.5 & \\
\hline Solid State & 2.5 & & 17.0 & 3.3 & & 1.4 & 3.0 \\
\hline Offsite Subcontracts & 21.3 & 15.9 & 15.5 & 0.5 & 1.0 & 4.7 & 3.1 \\
\hline TOTALS & 169.1 & 160.6 & 137.4 & 118.4 & 51.4 & 55.4 & 120.0 \\
\hline
\end{tabular}


This page intentionally left blank. 


\section{Appendix C. Program Funding by ORNL Division/Office (FY 1993 Operating Costs)}

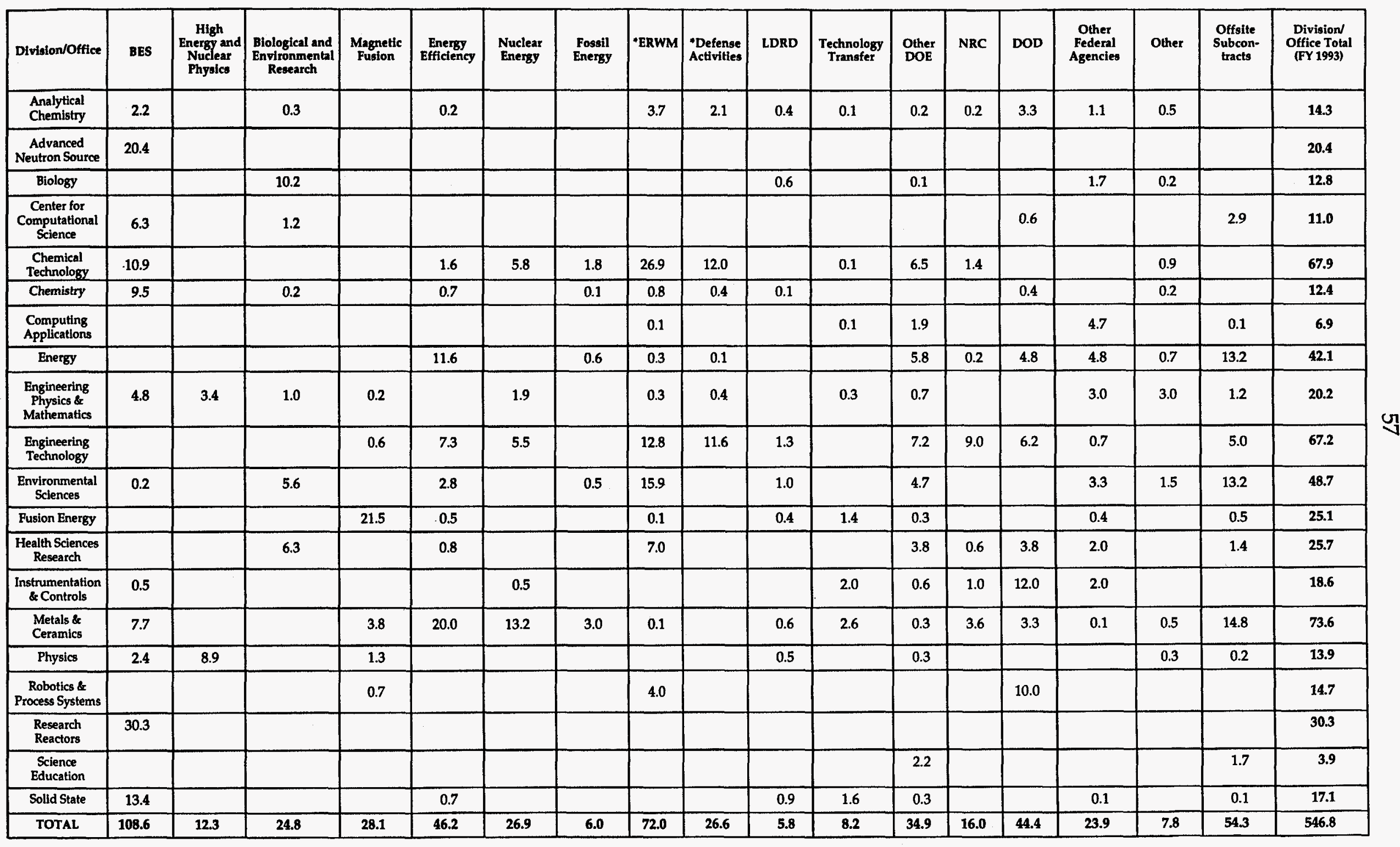

"Includes funding from Y-12 and K-25. 
1-2. T. D. Anderson

3. B. R. Appleton

4. J. B. Ball

5. F. E. Bertrand

6-7. B. A. Berven

8. D. J. Bostock

9. J. K. Bryson

10. D. F. Craig

11. I. B. Dunlap

12. M. P. Farrell

13. G. G. Fee

14. R. E. Fenstermaker

15. F. A. Figueroa

16. D. W. Erazier

17. W. Fulkerson

18. A. S. Garrett

19. C. W. Gehrs

20. H. A. Glovier

21. C. A. Grametbauer

22. L. E. Hall

23. P. E. Hall

24. J. I. Hammontree

25-26. F. C. Hartman

27. J. N. Herndon

28. J. R. Hickey

28-30. S. G. Hildebrand

31-32. R. B. Honea

33. C. C. Hopkins

34-35. J. E. Jones Jr.

36. K. I. Kliewer

37. M. W. Kohring

38. F. C. Kornegay

39. E. H. Krieg, Ir.

40. A. P. Malinauskas

41. W. R. Martin

42. R. C. Mason

43. D. W. MCDonald
44. L. E. MclNeese

45. G. E. Michaels

46-47. R. M. Moon, Jr.

48. F. R. Mynatt

49. C. E. Oliver

50. M. L. Poutsma

51. C. E. Pugh

52. D. E. Reichle

53. J. B. Richard

54. C. R. Richmond

55-59. J. B. Roberto

60. T. H. Row

61-70. M. J. Saltmarsh

71. A. C. Schaffhauser

72. J. Sheffield

73-74. R. B. Shelton

75. A. M. Shirley

76. C. S. Sims

77. R. F. Sincovec

78. K. W. Sommerfeld

79. D. R. Stallions

80. J. O. Stiegler

81. J. H. Swanks

82. C. C. Travis

83. A. W. Trivelpiece

84-85. R. C. Ward

86. D. A. Waters

87. C. D. West

88. G. E. Whitesides

89. R. M. Wilson

90. Central Research Library

91. Document Reference Section

92. Patent office-ORNL

93-94. Laboratory Records

95. Laboratory Records $R C$

\section{EXTERNAL DISTRIBUTION}

96. Dr. Sigfried Hecker, Director, Los Alamos National Laboratory, University of California, P. O. Box 1663, Los Alamos, NM 87545

97. Antionette G. Joseph, ER-80, Department of Energy, Washington, DC 20585

98. Martha A. Krebs, Director, Office of Energy Research, ER-1, Department of Energy, Washington, DC 20595 
99. Dr. William R. Wiley, Director, Pacific Northwest Laboratory, P.O. Box 999, Richland, WA 99352

100. Mr. William Marshall (Acting Director), National Renewable Energy Laboratory, 1617 Cole Blvd., Golden, CO 08401

101. Dr. Albert Narath, Director, Sandia National Laboratory, P.O. Box 5800, Albuquerque, NM 87185

102. Dr. Nicholas P. Samios, Director, Brookhaven National Laboratory, Upton, NY 11973

103. Dr. Charles V. Shank, Director, Lawrence Berkeley Laboratory, University of California, Berkeley, CA. 94720.

104. Dr. Alan Schriescheim, Director, Argonne National Laboratory, 9700 South Cass Ave., Argonne, IL 60439-4832

105. Marvin I. Singer, Deputy Assistant Secretary, Advanced Research and Special Technologies, FE-70, Department of Energy, Washington, DC 20585

106. Dr. Bruce Tarter (Acting Director), Lawrence Livermore National Laboratory, University of California, P.0. Box 808, Livermore, CA 94550 .

107. John M. Wilcynski, Acting Director, Idaho National Engineering Iaboratory, U.S. Department of Energy, Idaho Falls, ID 94550

108. Office of Assistant Manager for Energy Research and Development, U.S. Department of Energy, Oak Ridge Operations Office, P.O. Box 2001, Oak Ridge, TN 37831-8705

109-110. Office of Scientific and Technological Information, U.S. Department of Energy, P.O. Box 62, Oak Ridge, TN 37831 